\title{
LIVES OF THE BIGAMISTS
}

Marriage, Family, and Community in Colonial Mexico Richard Boyer

Cloth: 0-8263-1571-2 $\$ 40.00$

\section{OPPOSITION GOVERNMENT IN MEXICO}

Edited by Victoria E. Rodríguez and Peter M. Ward Cloth: 0-8263-1577-1 \$45.00 Paper: 0-8263-1578-X \$22.50

\section{HEROES ON HORSEBACK}

A Life and Times of the Last Gaucho Caudillos John Charles Chasteen Diálogos series

Cloth: 0-8263-1597-6 \$45.00 Paper: 0-8263-1598-4 \$19.95

\section{THE CONQUERORS OF THE NEW KINGDOM OF GRANADA}

José Ignacio Avellaneda

Cloth: $0-8263-1612-3 \quad \$ 50.00$

\section{ANDEAN JOURNEYS}

Migration, Ethnogenesis, and the State in Colonial Quito Karen Vieira Powers

Supported by a subvention from the National Endowment for the Humanities.

Cloth: $0-8263-1600-X \quad \$ 39.95$

UNIVERSITY OF NEW MEXICO PRESS At bookstores, or call 1-800-249-7737 FAX 1-800-622-8667 


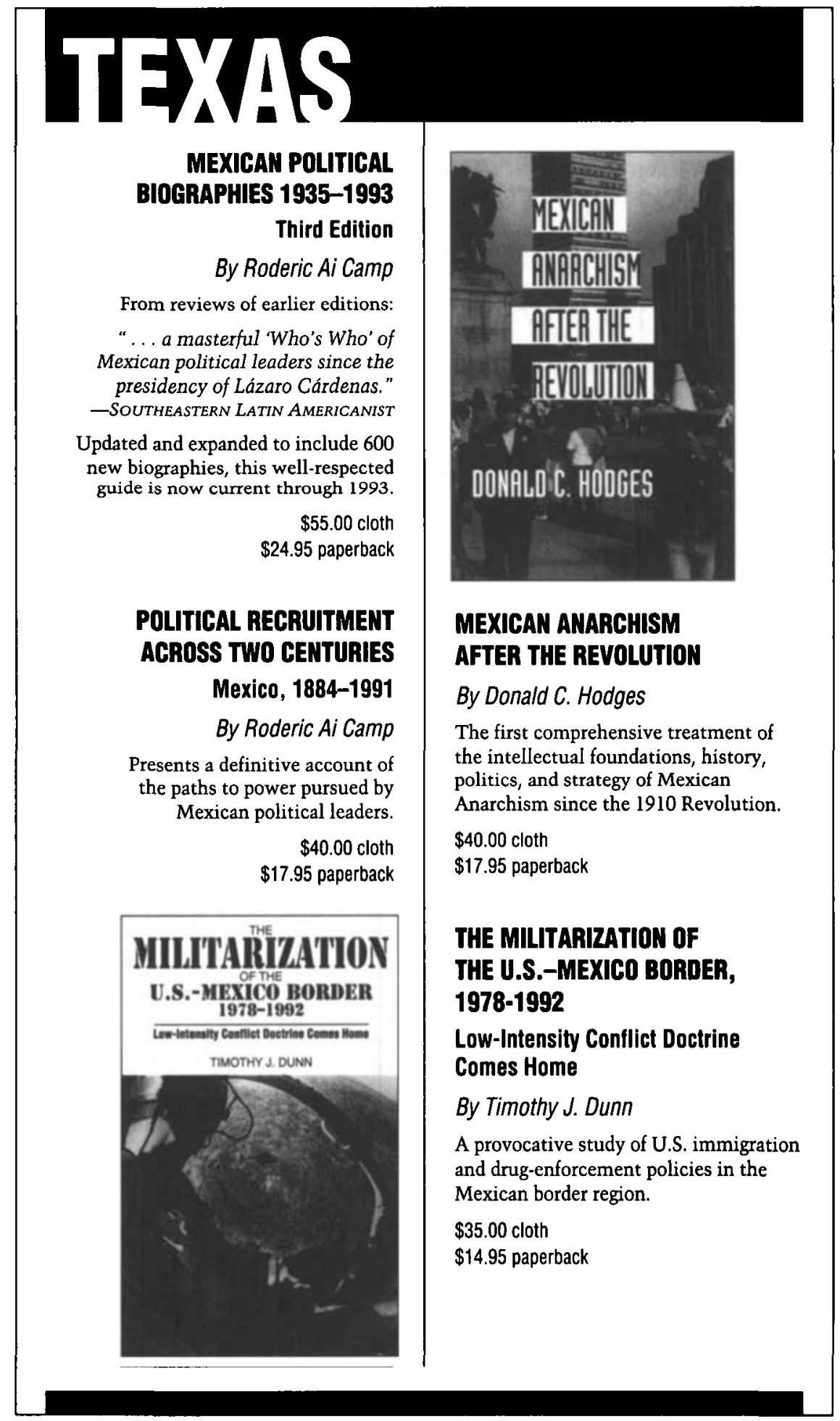




\section{CULTIVATING CRISIS}

The Human Cost of Pesticides in Latin America

\section{By Douglas L. Murray}

Since World War II, the Green

Revolution has been touted as the economic salvation of Latin America and other Third World regions, but few have publicly questioned the human cost of this bounty. After ten years of field research, Douglas Murray presents an interdisciplinary look at the consequences-including massive pesticide dependence, serious economic problems,

and shocking public health crisesof this far-reaching industry.

$\$ 35.00$ cloth $\$ 12.95$ paperback

\section{INHERIT THE ALAMO}

Myth and Ritual at an American Shrine

By Holly Beachley Brear

Examining the meaning of the Alamo through the eyes of numerous groupsfrom the Daughters of the Republic of

Texas to LULAC-Brear decodes the agendas and mythologies of the contesting

groups who lay claim to its heritage.

$\$ 19.95$ cloth

\section{TWENTIETH-CENTURY SPANISH AMERICAN FICTION}

\section{By Naomi Lindstrom}

Offering a comprehensive survey of this century's rich literary outpouring from Latin America, Lindstrom covers masterworks as well as lesser-known pieces that deserve a wider readership.

$\$ 37.50$ cloth

$\$ 15.95$ paperback

\section{REINTERPRETING THE} SPANISH AMERICAN ESSAY

Women Writers of the 19th and 20th Centuries

\section{Edited by Doris Meyer}

This volume of 21 original essays by noted experts celebrates the accomplishments of Latin American women essayists, from Gertrudis Gómez de Avellaneda to Elena Poniatowska.

$\$ 37.50$ cloth

\section{THE DISSERTING VOICE}

The New Essay of Spanish America, 1960-1985

\section{By Martin S. Stabb}

“... this is a pioneering, ground. breaking study."

- JONATHAN TITTLER, CORNELl UNIVERSITY

Stabb explores the writings of 26

Spanish American intellectuals whose dissent characterized the political and aesthetic changes of Latin American society from 1960 to 1985 .

$\$ 25.00$ cloth

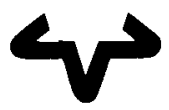

\section{UNIVERSITY OF TEXAS PRESS}

Box 7819 - Austin 78713

At fine bookstores, or call 800-252-3206. 


\section{FORO INTERNACIONAL}

VOL. XXXIV

ENERO-MARZO, 1994

NUM. 1

135

Artículos

Humberto Garza Elizondo

Democracia en Cuba

Carlos M. Vilas

Democratización y gobernabilidad en un escenario posrevolucionario: Centroamérica

\section{Victor Alarcón Olguín}

Polonia: consolidación democrática, elecciones y partidos

Miguel Carcia Reyes

Transición a la democracia en la Unión Soviética

Jean Meyer

¿Una apuesta imperial? Estrategia diplomática y militar de la Segunda República Rusa, 1992-1994

Tatiana Sidorenko

La privatización de empresas estatales en Rusia: alcances y perspectivas

FORO INTERNACIONAL es una publicación trimestral de El Colegio de México, A.C. Suscripción anual: en México, 76 nuevos pesos. En Estados Unidos y Canadá: individuos, 32 dólares; instituciones, 50. En Centro y Sudamérica: individuos, 26 dólares; instituciones, 34. En otros paises: individuos 42 dólares; instituciones 60 . Si desea suscribirse, favor de enviar este cupón a El Colegio de México. A.C. Departamento de Publicaciones, Camino al Ajusco 20. Col. Pedregal de Santa Teresa, 10740 México, D.F.

Adjunto cheque o giro bancario núm.:

por la cantidad de:

a nombre de El Colegio de México. A.C. como importe de mi suscripción por un año a FORO INTERNACIONAL.

Nombre:

Dirección:

Ciudad:

Código Postal:

Estado:

Pais: 


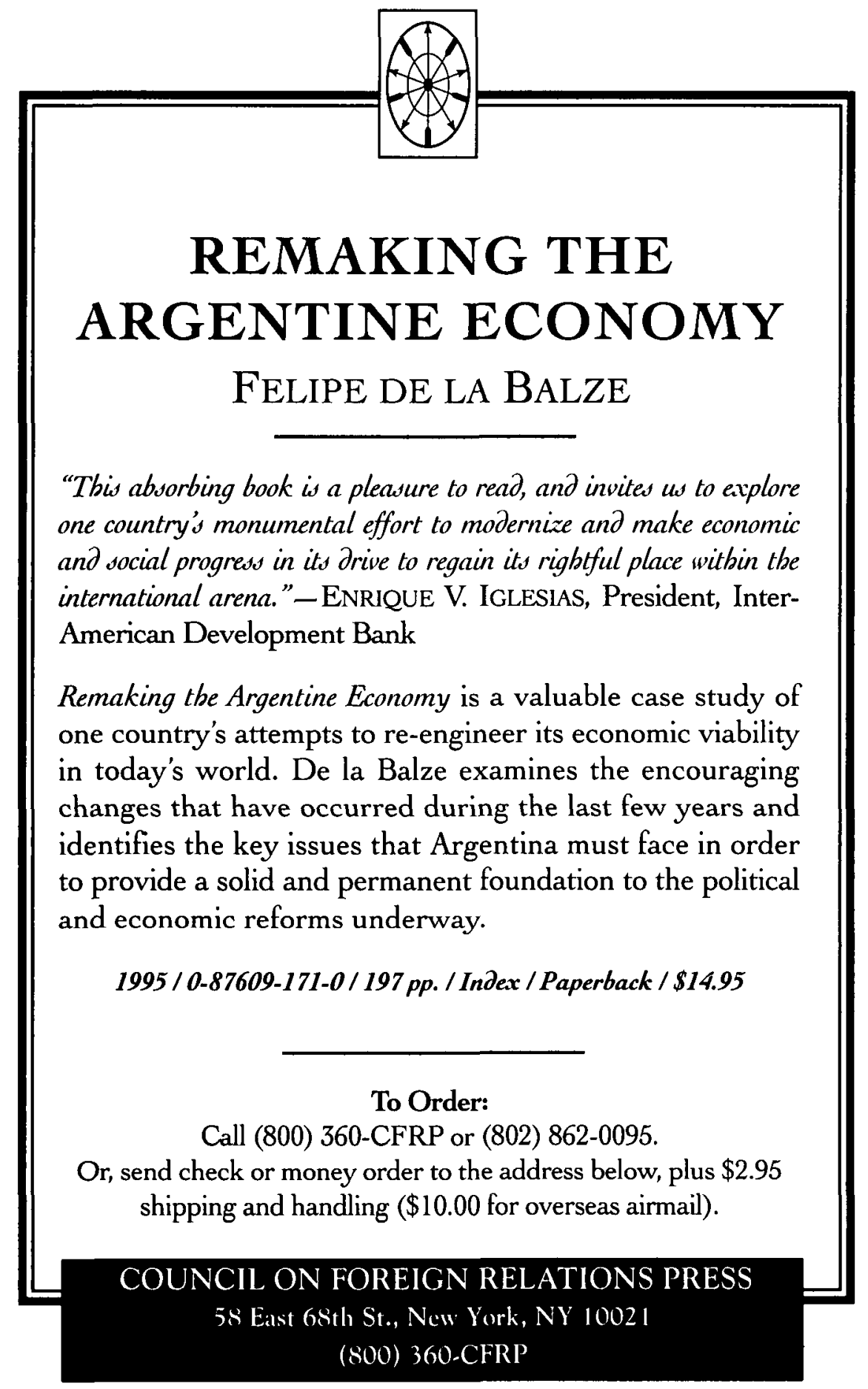




\title{
HISTORIA MEXICANA
}

\section{VOL. XLIV OCTUBRE-DICIEMBRE, $1994 \quad$ NUM. 2}

\section{4}

\section{ARTICULOS}

\author{
Rodolfo Pastor
}

De moros en la costa a negros de Castilla: representación y realidad en las crónicas del siglo XVII centroamericano

\section{Juan Pedro Viqueira \\ Tributo y sociedad en Chiapas}

\section{Victor Soria}

La incorporación del apartado del oro y la plata a la Casa de Moneda y sus resultados de operación, 1778-1805

\section{Rosalina Ríos Zúñiga}

La secularización de la enseñanza en Zacatecas. Del Colegio de San Luis Gonzaga al Instituto Literario (1784-1838)

HISTORIA MEXICANA es una publicación trimestral de El Colegio de México. A.C., Suscripción anual : en México, 76 nuevos pesos. En Estados Unidos y Canadá: individuos, 32 dólares; instituciones, 50 dólares. En Centro y Sudamérica: individuos, 26 dólares, instituciones, 34. En otros países: individuos, 42 dólares; instituciones 60 . Si desea suscribirse, favor de enviar este cupón a El Colegio de México, A.C. Departamento de Publicaciones, Camino al Ajusco 20, Pedregal de Santa Teresa, 10740 México, D.F.

Adjunto cheque 0 giro bancario núm.:

Por la cantidad de:

A nombre de El Colegio de México, A.C.por un año a HISTORIA MEXICANA Nombre:

Dirección:

Código postal:

Ciudad:

Estado:

País: 


\section{JULIA ALVAREZ}

IN THE TIME OF THE BUTTERFLIES

"An important book that will be consumed all over the New World, causing a furor of outrage and delight everywhere it is allowed to be read."-San Diego Tribume. $352 \mathrm{pp}$.

A Plume paperback $\quad 0-452-27442-7$

\$I I.95

HOMECOMING: New and Collected Poems

A Plume paperback $\quad 0-452-27567-9 \quad \$ 9.95$

Available December 1995

THE OTHER SIDE/EL OTRO LADO

A Dutron handcover $\quad 0-525-93922-9 \quad \$ 18.95$

\section{MARIO VARGAS LLOSA}

\section{A FISH IN THE WATER}

This vivid memoir reveals the roots of the political and literary forces that have made Llosa a world figure. "A perplexing and fascinating book." - San Francisco Chronicle. 544 pp A Penguin paperback $\quad 0.14024890-0 \quad \$ 13.95$

\section{ANA CASTILLO}

MASSACRE OF THE DREAMERS

Essays on Xicanisma

Castillo's critical examination of the 500-yearold roots of Chicano feminism in the United States. "Brilliant and powerfully written...these essays are testimony and proof of a revolutionary consciousness signaling change and real hope."-Ms. $258 \mathrm{pp}$

A Plume paperback $\quad$ 0-452-27424-9 \$11.95

\section{MARCELA BRETON, EDITOR}

RHYTHM AND REVOLT: Tales of the Antilles This exceptional collection, representing countries from Puerto Rico to Trinidad, features 24 works of Caribbean short fiction covering the 1920 s to the present day. $304 \mathrm{pp}$.

A Plume paperback original 0-452-27178-9

$\$ 12.95$

For a free Literature catalog, please call (2I2) 366-2372

PENGUIN U SA

ACADEMIC MARKETING DEPT. - 375 HUDSON ST. • NY, NY $10014-3657$

\section{New in paperback}

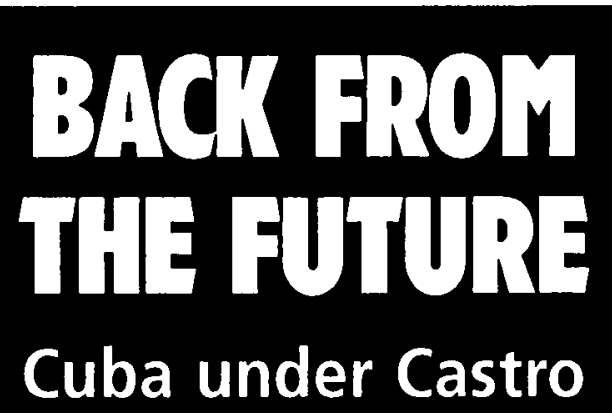

\section{SUSAN EVA ECKSTEIN}

\begin{abstract}
"A seminal, highly important, well-reasoned, and balanced analysis of Cuba under Castro. The author ... . examines Cuba in a fresh and complex way, marshaling impressive data on Cuban social and economic organization as well as on the inner workings of the revolutionary regime and its internal problems." -Choice
\end{abstract}

Now in paper: $\$ 15.95$ ISBN 0-691-02987-3 Due September 1995

\section{PRINCETON UNIVERSITY PRESS}

ORDER FROM YOUR BOOKSELLER OR DIRECTLY FROM THE PUBLISHER:

(609) 883-1759 U.S. (1243) 779777 U.K./EUROPE 


\title{
HISTORIA MEXICANA
}

\section{ARTÍCULOS}

\section{Manuela Cristina García Bernal Desarrollos indigena y ganadero en Yucatán}

Dorothy Tanck de Estrada

Escuelas y cajas de comunidad en Yucatán al final de la colonia

\section{Luis Alfonso Ramírez Carrillo \\ De buhoneros a empresarios: la inmigración libanesa en el Sureste de México}

\author{
Carlos Martínez Assad \\ Del fin del porfiriato a la Revolución en el sur-sureste de México \\ Gilbert M. Joseph y Allen Wells \\ Un replanteamiento de la movilización revolucionaria mexicana: \\ los tiempos de sublevación en Yucatán, 1909-1915
}

HISTORIA MEXICANA es una publicación trimestral de El Colegio de Mézdco, A.C.. Suscripción anual en México: 76 nuevos pesos. En Estados Unidos y Canadá: individuos, 32 dólares; instituciones, 50. En Centro y Sudamérica: individuos, 26 dólares; instituciones, 34. En otros paises: individuos, 42 dólares; instituciones, 60. Si desea suscribirse, favor de enviar a El Colegio de México, A.C. Departamento de Publicaciones, Camino al Ajusco 20, Col. Pedregal de Santa Teresa, 10740 México, D.F.

Cheque o giro bancario núm:

por la cantidad de:

a nombre de El Coleglo de Mérico, A.C., como importe de mi suscripción por un año a HISTORIA MEXICANA.

Nombre:

Dirección:

Código postal: Ciudad:

Estado: Pais: 


\section{The United Nations and}

\section{El Salvador 1990-1995}

The United Nations played a central role in the Salyadotian peace process, combining peace-making, peace-keeping and, especially post-conflict peacebuilding. The United Nations and El Salvador, 1990-1995, is a chronicle of one of the most comprehensive operations in the histony of the United Nations the United Nations Observer Mission in El Salvador (ONUSAl). Now, for the first time, the texts of more than $100 \mathrm{key}$ documents relating to this mission liave been brought together in as single voluime. Complementing the documents are a detailed

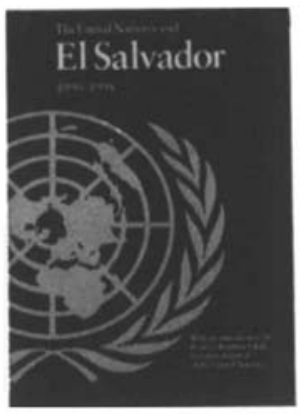
chironology and an introduction by Secretary-General Boutros Boutros-Ghali, which offer a complete account of the Organization's mulli-faceted work as mediaror, human rights monitor, peace-keeper ând electoral observer. Sales No. E.95.1.12 $1921100522 \% 3$, 2.9 .95

\section{The United Nations Blue Books Series}

Thisnew series of publications will prove an invaluable research and reference tool for academics, policy nakers, journalists and others interested in gaining a deeper understanding of the wort of the United Nations in dealing with the major issues of concern to humanity.

All the volumes will include an extensive introduction by Secretary-General Boutros Boutros Ghal, a detailed chronology of events and a collection of documents and related information.

Each is available at $\$ 2.995$.

Other titles in the series include:

-The United Nations and A partheld, 19481994

The United Nations and Cambodia, 1991-1995

- The United Nations and Nuclear Non-Proliferation

The United Nations and Mozambique, 1992-1995

Send Orders to:

United Nations Publications, Room DC2-0853, Dept. 344A, New York, N.Y. 10017

Tel. (800) 253-9646, (212) 963-8302, Fax. (212) 963-3489.

Visa, MC and AMEX accepted.

Please add $5 \%$ of gross (\$3.50 minimum) for shipping and handling. 


\title{
FORO INTERNACIONAL
}

\section{ARTICULOS}

\section{Carlos Alba Vega}

La microindustria ante la liberalización económica y el Tratado de Libre Comercio

\author{
Alejandro Nadal Egea \\ Procesos de producción, recursos naturales y comercio internacional en la zona \\ de libre comercio de Norteamérica
}
Alonso Lujambio
Presidentes y congresos. Esiados Unidos, la experiencia latinoamericana
y el futuro mexicano

Tatiana Sidorenko

La inserción de la economia de la antigua Unión Soviética en la economia mundial:

problemas y perspectivas

\section{Rosio Vargas Suarez}

La seguridad energética estadunidense de los setenta a los noventa

FORO IXTERYACION.AL es una publicación trimestral de El Colegio de México A.C.. Susctipción anual en Mexico: 76 nuevos pesos. En Estados Lnidos y Canadá: individuos. 32 dólares: instituciones. 50. En Centro y Sudamérica: individuos. 26 dólares: instituciones. 34. En otros paises: individuos. 42 dólares: instituciones. 60. Si desea suscribirse. favor de enviar a El Colegio de .Mexico. A.C., Deparamento de Publicaciones. Caminu al tjusco 20. Col. Pedregal de Santa Teresa. 107 t0 Mléxico. D.F.

Cheque o giro bancario num.:

por la cantidad de:

a nombre de El Colegio de México, A.C.. como importe de mi suscripción por un año a FORO INTERN.ACION.AL.

Nombre:

Direccion:

Código postal: Ciudad:

Estado: Pais: 


\title{
PROGRAM DIRECTOR \\ Latin America and the Caribbean
}

\section{Social Science Research Council}

The SSRC invites applications for a full-time Program Director to oversee/ administer all aspects of its programming conceming Latin America and the Caribbean.

Reporting to the President, collaborating with colleagues on the Council staff and the Joint Committee on Latin American Studies, the Director of the Latin America Program will initiate and oversee a wide variety of programs involving Latin America, as well as inter-regional initiatives which include a Latin American component.

The successful candidate will be expected to establish and maintain relationships with individual scholars, academic institutions, and foundations, and to serve as staff liaison to the Joint Committee on Latin American Studies. Specific responsibilities will include: helping to coordinate fellowship competitions; planning workshops, seminars and conferences; assisting with research planning functions of the Joint Committee on Latin American Studies and other Council panels; working with professional and support staff to oversee the day to day administative operation of the Program on Latin America and the Caribbean; and initiating new programs of collaborative research and training involving scholars from Latin America and other regions.

Applicants should hold a doctoral degree in the social sciences or demonstrate equivalent achievement, and must have a record of superior intellectual and administrative accomplishments. Previous experience in program design and implementation is preferred. Fluency in Spanish and English is essential with Portuguese desirable. Computer literacy is expected. Candidates will also be judged on their ability to work across a variety of intellectual fields. Candidates need not be U.S. citizens.

The position is based in New York City, and entails substantial international travel. SSRC staff are expected to continue their professional development.

Applications should be submitted to the address below. Review of candidates will begin immediately, and will continue until the position is filled. Salary and benefits are competitive. Applications from minority scholars and women are strongly encouraged.

Candidates should submit a letter of application, a curriculum vitae, and three letters of reference to:

\author{
D. Sinocchi \\ Social Science Research Council \\ 605 Third Ave \\ New York, NY 10158
}

The SSRC is an equal opportunity employer 


\section{CAMBRIDGE}

\section{NOW IN PAPERBACK stanford from \\ Armature of \\ Conquest \\ Spanish Accounts of the Discovery of America, 1492-1589}

Beatriz Pastor Bodmer

Translated by Lydia Longstreth Hunt

'A quite splendid book illustrating the power of post-structuralist questions to reframe the ways in which we read sixteenth-century Spanish narratives.' Journal of Latin American Studies f12.95 net PB $0804724709 \quad 340$ pp.

NOW IN PAPERBACK Stanford from The Nahuas After the Conquest

A Social and Cultural History of the Indians of Central Mexico, 16th through 18th Centuries

James Lockbart

'A monumental achievement of scholarship, this volume on the Nahua Indians of central Mexico constitutes our best understanding of any New World indigenous society in the period following European contact ... Lockhart's study is required reading.'

f17.95 net PB $0804723176 \quad 670$ pp.

\section{Church and State in Bourbon Mexico}

The Diocese of Michoacán 1749-1810

D. A. Brading

This is a rounded portrait of the Mexican Church at its meridian, touching upon virtually all aspects of religious life.

£40.00 net HB $0521460921 \quad 304$ pp.

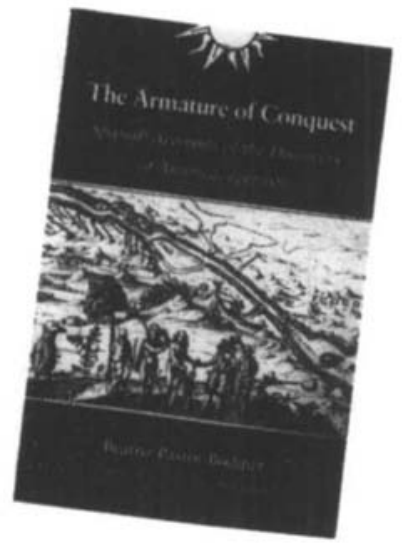

Tales of the Cance Yanomami

Daily Life in the Venezuelan Forest Jacques Lizot

'... an outstanding work ... deserves to be widely read, not just by anthropologists but by all who have an interest in understanding tribal societies.' Joumal of Latin American Studies f6.95 net PB $0521406722 \quad 212$ pp.

\section{Rural Guatemala, stanford from 1760-1940}

David McCreery

This comprehensive study of rural development in Guatemala examines the nature of rural society in the late colonial period and the early decades of independence, and then details the massive changes caused by the spread of large-scale coffee production after the $1850 \mathrm{~s}$.

f37.50 net HB $0804723184 \quad 464 \mathrm{pp}$.

Stanford University Press books are distributed outside North America by Cambridge University Press

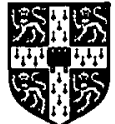

\section{CAMBRIDGE UNIVERSITY PRESS}

The Edinburgh Building, Cambridge CB2 2RU 


\section{CAMBRIDGE}

NOW IN PAPERBACK

Patronage \&

Politics in 19th Century

Brazil

\section{Richard Graham}

Focusing on the period from 1840 to 1889 , the author explores the specific ways in which granting protection, official positions, and other favours in exchange for political and personal loyalty worked to benefit the interests of wealthy Brazilians.

f13.95 net PB $0804723362 \quad 400$ pp. f17.95 net PB 0804723176

\section{NOW IN PAPERBACK}

\section{Resistance and Integration} Peronism and the Argentine Working Class, 1946-1976

Daniel James

This book analyses the relationship between Peronism and the Argentine working class from the foundation of the Peronist movement in the mid 1940s to the overthrow of Peron's widow in 1976. f14.95 net PB $0521466822 \quad 320$ pp. Cambridge Latin American Studies 64

\section{NOW IN PAPERBACK Stanford from The Decline of} Community in Zinacantan Economy, Public Life, and Social Stratification, 1960-1987

\section{Frank Cancian}

This ambitious anthropological study shows how national prosperity and government expansion in Mexico in the 1970's transformed a relatively closed peasant community into a more outwardly connected, socially differentiated society marked by dissension and conflict.

\section{Business Interest Groups in Nineteenth-Century Brazil \\ Eugene Ridings}

This is the first book to describe the role of business interest groups, also known as pressure groups, in the development of Brazil during the nineteenth century. f35.00 net HB $0521454859 \quad 400$ pp. Cambridge Latin American Studies 78

\section{The Politics of Human Rights in Stanford from CAMlikulut: Argentina} Alison Brysk

Under Argentina's military dictatorship of 1976-83, tens of thousands of Argentine citizens disappeared - having been abducted, tortured and finally murdered by the government. This book is the most comprehensive account of the only force that resisted such atrocities: the Argentine human rights movement.

$£ 30.00$ net HB $0804722757 \quad 308$ pp.

\section{Strong Parties Stanford from and Lame Ducks CAMlikil)(il:} Presidential Partyarchy and Factionalism in Venezuela

\section{Michael Coppedge}

This bold and comprehensive reassessment of democracy in Venezuela explains why one of the oldest and most admired democracies in Latin America is in danger of collapsing after more than three decades of apparent stability.
f10.95 net PB 0804723621
324 pp.

Stanford University Press books are distribured outside North America by Cambridge University Press
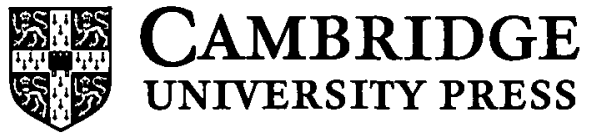

The Edinburgh Building, Cambridge CB2 2RU 


\section{EL TRIMESTRE $\mathrm{E} C$
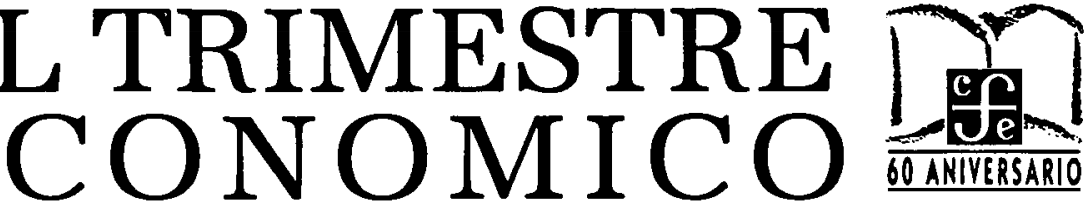

COMITÉ DICTAMINADOR: Carlos Bazdresch P., Pablo Cotler, Raúl Garcia, Raúl Livas, Lucia Segovia, Rodolfo de la Torre. CONSEJO EDITORIAL: Edmar L. Bacha, José Blanco, Gerardo Bueno, Enrique Cárdenas, Arturo Fernández, Ricardo Firench-Davis, Enrique Florescano, Roberto Frenkel, Ricardo Hausmann, Aibert O. Hirschman, David Ibarra, Francisco Lopes, Guillermo Maldonado, José A. Ocampo, Luis Ángel Rojo Duque, Gert Rosenthal, Fernando Rosenzweig (t), Francisco Sagasti, Jaime José Serra, Jesús Silva Herzog Flores, Osvaldo Sunkel, Carlos Tello.

\section{Director: Carlos Bazdresch P. Subdirector: Rodolfo de la Torre Secretario de Redacción: Guillermo Escalante A.}

Vol. LXI (4)

México, Octubre-Diciembre de 1994

Núm. 244

\section{ARTICULOS}

Douglass C. North

Juan Tugores y Gonzalo Bernados

George M. von Furstenberg

Hugo Mena Keymer

NOTAS Y COMENTARIOS: José Rodríguez González, Gasto público en educación y distribución del ingreso en el Perú

El Trimestre Económico aparece en los meses de enero, abril, julio y octubre. La suscripción en México cuesta N\$100.00. Número suelto $\mathbf{N} \$ 35.00$. Indices de números 1-200 (por autores y temático) $N \$ 7.50$

Precio de suscripción por un año, 1995

$$
\text { España, Centro y Sudamérica }
$$$$
\text { (dolares) }
$$

Personal

Número suelto

Índice de números $1-200$

Universidades, bibliotecas e instituciones Número suelto
35.00

12.00

20.00

42.00

30.00

\section{Resto del mundo} (dolares)

42.00

18.00

50.00

120.00

42.00

Fondo de Cultura Económica, carretera Picacho Ajusco 227, Col. Bosques del Pedregal, 14200 México, D.F. Suscripciones y anuncios: teléfono 227-46-70, señora Irma Barrón. 
NEW FROM

\section{CAMBRIDGE}

\section{The Cuban Slave Market, $1790-1880$ \\ Laird W. Bergad, \\ Fe Iglesias García, and \\ María del Carmen Barcia}

This volume presents a quantitative study of Cuban slavery from the late eighteenth century until 1880 , the year slavery was formally abolished on the island. It examines the yearly movement of slave prices and changes in the demographic characteristics of the slave market. Incorporating over 30,000 slave transactions from three separate locations in Cuba-Havana, Santiago, and Cienfuegos-this work comprises the largest extant data base on any slave market in the Americas.

Cambridge Latin American Studies 79

48059-0 Hardback \$59.95

\section{The Cambridge History of Latin America}

Volume 10: Latin America since 1930: Ideas, Culture, and Society

\section{Leslie Bethell, Editor}

This volume discusses the modernist culture of the 1920s in Brazil, Argentina, and Mexico; the renaissance of Latin American philosophy in the 1940s; major trends in Latin American narrative and poetry; the work of twentieth-century Latin American composers, architects, filmmakers, and artists; and the Latin American mass media.

Contributors: Richard M. Morse, Gerald Martin, Jaime Concha, Jason Wilson, Gordon Brotherston, Gérard Behague, Damián Bayón, John King, Elizabeth Fox

49594-6 Hardback

about $\$ 110.00$

Available in bookstores or from AMBRIDGE

\section{UNIVERSITY PRESS}

40 West 20th St., N.Y., NY 10011-4211 Call toll-free 800-872-7423.

MasterCard/VISA accepted.

Prices subject to change

Web site: http://www.cup.org

\section{The Kingdom of Quito,} 1690-1830

The State and Regional Development

\section{Kenneth J. Andrien}

Spanish colonialism exacted a high price from its subjects, promoting economic dependency at the the expense of a more vital, diversified economy based on a mix of industry and agriculture. This volume examines how Spanish colonial policies contributed to profound socioeconomic changes, leading to patterns of underdevelopment in the Kingdom of Quito (modern Ecuador) from 1690 to 1830 . Cambridge Latin American Studies 80 48125-2 Hardback \$59.95

\section{Global Change, Regional Response}

The New International Context of Development

\section{Barbara Stallings, Editor}

Offering a new perspective on studying contemporary development, this study explores how the ending of the Cold War, shifting relations among capitalist powers, changing patterns of finance, and new ideological currents have altered development in four major third-world regions.

Contributors: Barbara Stallings, Fred Halliday, Wolfgang Streeck, Gary Gereffi, Stephany GriffithJones, Thomas J. Biersteker, Yun-han Chu, Linda Y.C. Lim, Augusto Varas, Michael Chege

47227-X Hardback \$59.95

47806-5 Paperback \$17.95

\section{The Haiti Crisis in} International Law Marc Weller, Editor Ana MacLean, Assistant Editor The Haiti episode represents the first and only instance of a UN-mandated military operation to restore democracy, against the wishes of an effective government in the target state. This volume documents the crisis from the initial coup, the immediate responses of the United Nations and the Organization of American States (OAS), the application of sanctions, attempts to negotiate a transfer of power, to the deployment of U.S. forces in Haiti. Cambridge International Documents Series 10 55048-3 Hardback about $\$ 150.00$ 


\section{Journal of \\ Latin American \\ Studies}

VOLUME 27 I995

EDITORS

VICTOR BULMER-THOMAS

LAURENCE WHITEHEAD

EDITORIAL BOARD

VICTOR BULMER-THOMAS

PAUL CAMMACK

JAMES DUNKERLEY

JOHN FISHER

PETER FLYNN

JOSEPH FOWERAKER

BRIAN HAMNETT

OLIVIA HARRIS

ALAN KNIGHT

DAVID LEHMANN

SARAH RADCLIFFE

LAURENCE WHITEHEAD

PART I pages $1-290$

PART 2 pages 29I- 15

PART 3 pages $517-758$

\section{CAMBRIDGE}


Published by the Press Syndicate of the University of Cambridge The Pitt Building, Trumpington Street, Cambridge, СВ 2 IRP 40 West 2oth Street, New York, NY I00I I-4211, U.S.A.

Io Stamford Road, Oakleigh, Melbourne 3166, Australia

(C) Cambridge University Press r995 


\section{Articles}

Beckrrman, Paul: Central-Bank 'Distress' and Hyperinflation in Argentina, 1989-90

Boone, Christopher: Streetcars and Politics in Rio de Janeiro: Private Enterprise versus Municipal Government in the Provision of Mass Transit, 1903-1920

Childs, Matt D.: An Historical Critique of the Emergence and Evolution of Ernesto Che Guevara's Foco Theory

Clark, Truman R.: Prohibition in Puerto Rico, 1917-1933

Dracon, Todd: Bringing the Countryside Back In: A Case Study of Military Intervention as State Building in the Brazilian Old Republic

Gleijeses, Piero: Ships in the Night: The CIA, the White House and the Bay of Pigs

KIDD, Stephen W.: Land, Politics and Benevolent Shamanism: The Enxet Indians in a Democratic Paraguay

Murdock, Carl. J.: Physicians, the State and Public Health in Chile, $\mathrm{I} 88 \mathrm{I}-\mathrm{I} 89 \mathrm{I}$

Porcile, Gabriel: The Challenge of Cooperation: Argentina and Brazil, I939-5S

Rosenthal, Anton: The Arrival of the Electric Streetcar and the Conflict over Progress in Early 2oth Century Montevideo

Serrano, Monica: The Armed Branch of the State: Civil-Military Relations in Mexico

SIEDER, Rachel: Honduras: The Politics of Exception and Military Reformism (1972-78)

Starn, Orin: Maoism in the Andes: The Communist Party of PeruShining Path and the Refusal of History

Stoller, Richard: Alfonso López Pumarejo and Liberal Radicalism in I 930 S Colombia

Thurner, Mark: 'Republicanos' and 'la Comunidad de Peruanos': Unimagined Political Communities in Postcolonial Andean Peru

URIBE, Victor M.: The Lawyers and New Granada's Late Colonial State WeLCH, Cliff: Rivalry and Unification: Mobilising Rural Workers in São Paulo on the Eve of the Brazilian Golpe of 1964

Willis, Eliza J: Explaining Bureaucratic Independence in Brazil: The Experience of the National Economic Development Bank 


\section{Commentaries}

Angell, Alan and Graham, Carol: Can Social Sector Reform Make Adjustment Sustainable and and Equitable? Lessons from Chile and Venezuela

Kallendorf, Hilaire: A Myth Rejected: The Noble Savage in Dominican Dystopia

Mas, Ignacio: Policy-Induced Disincentives to Financial Sector Development: Selected Examples from Latin America in the $1980 \mathrm{~s}$

\section{Reviews}

Aedo, Cristián and Larranaga, Osvaldo (eds.), Social Service Delivery Systems: An Agenda for Reform, reviewed by Alan Angell

Aguirre, Carlos, Agentes de su propia libertad: Los esclavos de Lima y la desintegración de la esclavitud $1821-1854$, reviewed by Paul Gootenberg

Alcantara Saez, Manuel and Crespo Martinez, Ismael, Partidos politicos y procesos electorales en Uruguay (1971-1990), reviewed by Martin Weinstein

Alegria, Fernando, Allende: A Novel, Translated by Frank Janney, reviewed by Jorge Heine

Almeida, Rebecca, Kemmerer en el Ecuador, reviewed by Paul W. Drake

Amaral, Samuel and Plotkin, Mariano Ben (eds.), Perón del exilio al poder, reviewed by Richard Gillespie

Anderson, Leslie E., The Political Ecology of the Modern Peasant: Calculation and Community, reviewed by J. Martinez-Alier

Andrien, Kenneth J. and Johnson, Lyman L. (eds.), The Political Economy of Spanish America in the Age of Revolution, 1750-1850, reviewed by John Lynch

BaEr, Werner and Tulchin, Joseph S. (eds.), Brazil and the Challenge of Economic Reform, reviewed by Susan M. Cunningham

Baloyra, Enrique A. and Morris, James A. (eds.), Confict and Change in $C u b a$, reviewed by Jorge I. Dominguez

Barthelemy, Gérard and Girault, Christian (eds.), La République baitienne: État des lieux et perspectives, reviewed by James Ferguson

Bastian, Jean-Pierre, Le protestantisme en Amérique latine: Une approche socio-bistorique, reviewed by Virginia Garrard Burnett

Bebbington, Anthony, Thiele, Graham et al., Non-Governmental Organizations and the State in Latin America: Retbinking Roles in Sustainable Agricultural Development, reviewed by Jutta Blauert

Bengelsdorf, Carollee, The Problem of Democracy in Cuba: Between Vision and Reality, reviewed by Enrique Baloyra

Berins Collier, Ruth, The Contradictory Alliance: State-Labor Relations and Regime Change in Mexico, reviewed by Ilán Bizberg 
Brondi-Morra, Brizio N., Hungry Dreams: The Failure of Food Policy in Revolutionary Nicaragua, 1979-1990, reviewed by Max Spoor

Block, David, Mission Culture on the Upper Amazon: Native Tradition, Jesuit Enterprise and Secular Policy in Moxos, 1660-1880, reviewed by Linda A. Newson

Bosworth, Barry P., Dornbusch, Rudiger and Laban, Raúl (eds.), The Chilean Economy: Policy Lessons and Challenges, reviewed by J. M. Albala-Bertrand

Brading, D. A., Church and State in Bourbon Mexico: The Diocese of Micboacán 1749-1810, reviewed by Margaret Chowning

Bulmer-Thomas, Victor, Craske, Nikki and Serrano, Mónica (eds.), Mexico and the North American Free Trade Agreement: Who Will Benefit?, reviewed by Sidney Weintraub

Bulmer-Thomas, Victor, The Economic History of Latin America since Independence, reviewed by John $\mathrm{H}$. Coatsworth

Bunck, Julie Marie, Fidel Castro and the Quest for a Revolutionary Culture in Cuba, reviewed by Jean Stubbs

Burdick, John, Looking for God in Brazil: The Progressive Catholic Church in Urban Brazil's Religious Arena, reviewed by W. E. Hewitt

Camp, Roderic, Ai, Politics in Mexico, reviewed by Nikki Craske

Carmagnani, Marcello (ed.), Federalismos latinoamericanos: México/ Brasil/Argentina, reviewed by Tulio Halperín-Donghi

Carmagnani, Marcello, Estado y mercado: La economia pública del liberalismo mexicano, $1850-1911$, reviewed by Will Fowler

CARR, Barry, Marxism and Communism in Twentietb-Century Mexico, reviewed by Nikki Craske

Castaneda, Jorge, Utopia Unarmed: The Latin American Left after the Cold War, reviewed by Alan Angell

Cavaliero, Roderick, The Independence of Brazil, reviewed by John Lynch

Cerdas-Cruz, Rodolfo, The Communist International in Central America, 1920-36, reviewed by Nicola Miller

Cervantes, Fernando, The Devil in the Nen World: The Impact of Diabolism in New Spain, reviewed by Patricia Seed

Cope, R. Douglas, The Limits of Racial Domination: Plebeian Society in Colonial Mexico City, I660-1720, reviewed by Jonathan Israel

Cornelius, Wayne A., Craig, Ann L. and Fox, Jonathan (eds.), Transforming State-Society Relations in Mexico: The National Solidarity Strategy, reviewed by Rubén Hernández León

Corten, André, El estado débil: Haití y la República Dominicana, reviewed by Mats Lundahl

Costeloe, Michael P., The Central Republic in Mexico, 1835-1846: Hombres de Bien in the Age of Santa Anna, reviewed by G. P. C. Thomson

D'Incao, Maria Angela and Maciel da Silveira, Isolda (eds.), Amazônia e a Crise da Modernização, reviewed by Darrell A. Posey

Davis, Diane E., Urban Leviathan: Mexico City in the Twentieth Century, reviewed by Gareth A. Jones

Deas, Malcolm, Del poder y la gramática. Y otros ensayos sobre bistoria, politica y literatura colombianas, reviewed by Eduardo Posada-Carbó 
Dijkstra, Geske, Industrialization in Sandinista Nicaragua: Policy and Practice in a Mixed Economy, reviewed by G. W. Irvin

Dorner, Peter, Latin American Land Reforms in Theory and Practice: A Retrospective Analysis, reviewed by C. D. Scott

Dunkerley, James, The Pacification of Central America, reviewed by Edelberto Torres-Rivas

Eckstein, Susan Eva, Back from the Future: Cuba under Castro, reviewed by Enrique Baloyra

Ellner, Steve, Organized Labor in Venequela 1958-1991: Bebaviour and Concerns in a Democratic Setting, reviewed by Alan Angell

Foweraker, Joe, Popular Mobilization in Mexico: The Teachers' Movement, 1977-87, reviewed by Nikki Craske

GAYOL, Roberto, Dos problemas de vital importancia para México: La colonización y el desarrollo de la irrigación, reviewed by José Estéban Castro

Gill, Lesley, Precarious Dependencies: Gender, Class, and Domestic Service in Bolivia, reviewed by Georgina Waylen

Gootenberg, Paul, Imagining Development: Economic Ideas in Peru's "Fictitious Prosperity" of Guano, I840-I880, reviewed by Rory Miller

Graham, Carol, Safety Nets, Politics, and the Poor: Transitions to Market Economies, reviewed by Peter Lloyd-Sherlock

Greer Johnson, Julie, Satire in Colonial Spanish America: Turning the New World Upside Down, reviewed by Gordon Brotherston

Grosh, Margaret E., Administering Targeted Social Programs in Latin America: From Platitudes to Practice, reviewed by Carol Graham

Guevara Gil, Jorge A., Propiedad agraria y derecho colonial: Los documentos de la bacienda Santotis Curco (I543-I822), reviewed by John Fisher

Guzman Bouvard, Marguerite, Revolutionizing Motherbood: The Mothers of the Plaza de Mayo, reviewed by Georgina Waylen

Hale, Charles R., Resistance and Contradiction: Miskitu Indians and the Nicaraguan State, $1894-1987$, reviewed by Peter Sollis

Harvey, Neil, Rebellion in Chiapas: Rural Reforms, Campesino Radicalism, and the Limits to Salinismo, reviewed by Nikki Craske

Hennessy, Alistair and Lambie, George (eds.), The Fractured Blockade: West European-Cuban Relations During the Revolution, reviewed by Hugh O'Shaughnessy

Hernandez Chavez, Alicia, La tradición republicana del buen gobierno, reviewed by G. P. C. Thomson

Herrera y Lasso, José, Apuntes sobre irrigación: Notas sobre su organización económica en el extranjero y en el país, reviewed by José Estéban Castro

Hess, David J., Samba in the Night: Spiritism in Brazil, reviewed by Stephen Nugent

Hirabayashi, Lane Ryo, Cultural Capital: Mountain Zapotec Migrant Associations in Mexico City, reviewed by Joseph W. Whitecotton

Huenefeldt, Christine, Paying the Price of Freedom: Family and Labor among Lima's Slaves, $1800-1854$, reviewed by Paul Gootenberg

Jackson, Robert H., Indian Poputation Decline: The Missions of Nortbwestern New Spain, $1687-1840$, reviewed by Linda A. Newson 
Joergensen, Beth E., The Writing of Elena Poniatowska: Engaging Dialogues, reviewed by Catherine Davies

KInsbruner, Jay, Independence in Spanish America: Civil Wars, Revolutions and Underdevelopment, reviewed by John Lynch

KLEIN, Herbert S., Haciendas and 'Ayllus': Rural Society in the Bolivian Andes in the Eighteenth and Nineteenth Centuries, reviewed by Olivia Harris

Klepak, Hal P. (ed.), Canada and Latin American Security, reviewed by Andrew Hurrell

Lavaud, Jean-Pierre, L'instabilité de l'Amérique latine: le cas bolivien, reviewed by Pilar Domingo

Lesser, Jeffrey, Welcoming the Undesirables: Brazil and the Jewish Question, reviewed by Robert M. Levine

Levenson-Estrada, Deborah, Trade Unionists Against Terror: Guatemala City $1954-1985$, reviewed by Henry Frundt

Lewis, Colin M. and Torrents, Nissa (eds.), Argentina in The Crisis Years (1983-1990): From Alfonsin to Menem, reviewed by Celia Szusterman

Linz, Juan J. and Valenzuela, Arturo (eds.), The Failure of Presidential Democracy, reviewed by Pilar Domingo

Liss, Sheldon B., Fidel! Castro's Political and Social Thought, reviewed by Jean Stubbs

Lopez-Alves, Fernando, Between the Economy and the Polity in the River Plate: Uruguay, $1811-1890$, reviewed by Henry Finch

MaIngot, Anthony P., The United States and the Caribbean, reviewed by Lester Langley

Major, John, Prize Possession: The United States and the Panama Canal, 1903-1979, reviewed by Sheldon B. Liss

Mariz, Cecilia Loreta, Coping with Poverty: Pentecostals and Christian Base Communities in Brazil, reviewed by Alba Zaluar

Martin, Luther (ed.), Religious Transformations and Socio-Political Change: Eastern Europe and Latin America, reviewed by Ralph della Cava

Mayo, Carlos A. and Latrubesse, Amalia, Terratenientes, soldados y cautivos: La Frontera (1736-1815), reviewed by John Lynch

Mazzeo, Cristina Ana, El Comercio Libre en el Perú: las estrategias de un comerciante criollo: José Antonio de Lavalle y Cortés Conde de Premio Real, $1777-1815$, reviewed by John Fisher

MCCREerY, David, Rural Guatemala: $1760-194^{\circ}$, reviewed by Doug Yarrington

Melville, Elinor G. K., A Plague of Sheep: Environmental Consequences of the Conquest of Mexico, reviewed by J. Martínez Alier

Mezzera, Jaime (ed.), Crédito Informal: Acceso al Sistema Financiero, reviewed by Jim Thomas

Miller, Rory and NoBle, Pat, Information Technology for Latin Americanists, reviewed by Peter Cleaves

Moerner, Magnus, Region and State in Latin America's Past, reviewed by Eduardo Posada-Carbó

Morley, Morris H., Washington, Somoza, and the Sandinistas: State and Regime in U.S. Policy toward Nicaragua, 1969-1981, reviewed by William M. LeoGrande 
Morris, Michael A. Caribbean Maritime Security, reviewed by Varun Sahni Murillo, Gabriel C. (ed.), Hacia la consolidación democrática andina:

Murray, Douglas L., Cultivating Crisis: The Human Cost of Pesticides in Latin America, reviewed by Michael Redclift

Naranjo Orovio, Consuelo and Mallo Gutierrez, Tomás (eds.), Cuba la perla de las Antillas: Actas de las I Jornadas sobre "Cuba y su Historia", reviewed by Jean Stubbs

Navarro, Juan Carlos, (ed.), Community Organizations in Latin America, reviewed by Alan Angell

Navas Blanco, Alberto, Las elecciones presidenciales en Venezuela del siglo $X I X, 1830-1854$, reviewed by John Lynch

Painter, James, Bolivia and Coca: A Study in Dependency, reviewed by Madeline Barbara Leons

Palacios, Leopoldo, El problema de la irrigación, reviewed by José Estéban Castro

Petras, James and Leiva, Fernando Ignacio et al., Democracy and Poverty in Chile: The Limits to Electoral Politics, reviewed by Philip Oxhorn

Puleo, Mev, The Struggle is One: Voices and Visions of Liberation, reviewed by John Burdick

Pyne, Leigh A., Brazilian Industrialists and Democratic Change, reviewed by Eduardo Silva

Quirk, Robert E., Fidel Castro: The Full Story of bis Rise to Power, bis Regime, bis Allies, and bis Adversaries, reviewed by Ana Covarrubias

Rakowski, Cathy A. (ed.), Contrapunto: The Informal Sector Debate in Latin America, reviewed by Dr. J. P. Pérez Sáinz

Ridings, Eugene, Business Interest Groups in Nineteenth-Century Brazil, reviewed by Steven $C$. Topik

Rochlin, James, Discovering the Americas: The Evolution of Canadian Foreign Policy Towards Latin America, reviewed by Alan Angell

Rock, David (ed.), Latin America in the 1940s: War and Postwar Transitions, reviewed by Carlos Escudé

Rodriguez, Jaime O. (ed.), Mexico in the Age of Democratic Revolutions, $1750-1850$, reviewed by Will Fowler

Rodriguez, Jeanette, Our Lady of Guadalupe: Faith and Empowerment among Mexican-American Women, reviewed by Patricia Seed

Rostas, Susanna and Droogers, André (eds.), The Popular Use of Popular Religion in Latin America, reviewed by David Lehmann

Rottenberg, Simon, The Political Economy of Poverty, Equity, and Growth: Costa Rica and Uruguay, reviewed by Henry Finch

Salazar-Carillo, Jorge, Oil and Development in Venequela during the Twentieth Century, reviewed by Juan Carlos Boué

Santiago-Valles, Kelvin A., "Subject People" and Colonial Discourses: Economic Transformation and Social Disorder in Puerto Rico, 1898-1947, reviewed by Lany Thompson

Schoultz, Lars, Smith, William C., and Varas, Augusto (eds.), Security, Democracy, and Development in U.S.-Latin American Relations, reviewed by Nicola Miller 
Schulz, Donald E. and Sundloff Schulz, Deborah, The United States, Honduras, and the Crisis in Central America, reviewed by Rachel Sieder

Shapiro, Helen, Engines of Growth: The State and Transnational Auto Companies in Brazil, reviewed by John Humphrey

Silva, Eduardo, Prince of the People: The Life and Times of a Brazilian Free Man of Colour, reviewed by Sandra Lauderdale Graham

Sмiтн, Peter H. (ed.), The Challenge of Integration: Europe and the Americas, reviewed by Andrew Hurrell

SPAlding, Rose J., Capitalists and Revolution in Nicaragua: Opposition and Accommodation 1979-1993, reviewed by Richard Stahler-Sholk

Steinmetz, Sara, Democratic Transition and Human Rights: Perspectives on U.S. Foreign Policy, reviewed by Alexandra de Brito

Stewart, Douglas Ian, After the Trees: Living on the Transamazon Highway, reviewed by Stephen Nugent

Stoll, David, Between Two Armies in the Ixil Towns of Guatemala, reviewed by James Painter

Stone, Kenton V., Utopia Undone: The Fall of Uruguay in the Novels of Carlos Martinez Moreno, reviewed by Luis Rebaza-Soraluz

Urquiola S., Miguel, Participando en el crecimiento. Expansión económica, distribución del ingreso y pobreza en el área urbana de Bolivia: 1989-1992 y proyecciones, reviewed by Rhys Jenkins

Varas, Augusto and Caro, Isaac (eds.), Medidas de Confianza mutua en América Latina, reviewed by Andy Hurrell

Varasand, Augusto and Funetes, Claudio, Defensa nacional, Chile 1990-1994: Modernización y Desarrollo, reviewed by Andrew Hurrell

Viqueira Landa, Carmen and Torre Medina Mora, Lydia (eds.), Sistemas bidráulicos, modernización de la agricultura y migración, reviewed by José Estéban Castro

Wasserman, Mark, Persistent Oligarchs: Elites and Politics in Cbibuabua, Mexico 1910-1940, reviewed by Alan Knight

Watters, F., Poverty and Peasantry in Peru's Soutbern Andes, 1963-90, reviewed by John Crabtree

Zaverucha, Jorge, Rumor de Sabres: Controle civil ou tutela militar. Estudo comparativo das transigoes democráticas no Brasil, na Argentina e na Espanha, reviewed by Paul Cammack 


\section{CEPAL Review}

Santiaga, Chile

December 1994

Number 54

Health care markets: their morphology, behaviour and regulation

Jorge Katz and Ermesto Miranda

Liberalization or financial development?

Giunther Held

Fiscal adjustment and social spending

Rosella Cominetti

Women's formal education: achievements and obstacles

Diane Alméras

Labour market flexibility: what does it really mean?

Ricardo A. Lagos

The modernization of bank supervision

Christian Larrain

Central American integration: its costs and benefits

Luis Caceres

Some lessons of the Argentine privatization process

Daniel Azpiazu and Adolfo Vispo

Extraordinary comparative advantages and long-run growth: the

case of Ecuador

André A. Hoffman and Rudolf Buitelaar

The cultural industry and new codes of modernity Martin Hopenhayn

Guidelines for contributors to CEPAL Review

Recent ECLAC publications

Quarterly publication, in Spanish and English.

Value: US\$10 (or local currency equivalent).

Annual subscription: US\$16 (Spanish), and US\$18 (English).

Orders: ECLAC Distribution Unit, Casilla 179-D, Santiago, Chile; United Nations Publications, Sales Section, DC-2-866, New York, 10017, United States of America; Palais des Nations, 1211 Geneva 10, Switzerland. 


\section{NOTES FOR CONTRIBUTORS}

The Joumal of Latin American Studies is published three times a year, in February, May and October. Its editorial offices are located in the Institute of Latin American Studies, University of London. The editorial board includes representatives of the Centres or Institutes of Latin American Studies in the Universities of Cambridge, Essex, Glasgow, Liverpool, London and Oxford.

The scope of the Journal is the study of Latin America from the standpoint of the social sciences (including history and international relations). Articles on literature and the arts are not normally included, but the editors are pleased to consider contributions in the field of intellectual and cultural history. Articles with an inter-disciplinary approach are particularly welcome.

When an article has been accepted for publication, the author is strongly encouraged to send a copy of the final version on computer disk (Apple Macintosh or IBM compatible PC) together with the hard copy typescript, giving details of the wordprocessing software used (Microsoft Word or Word Perfect). However, the publisher reserves the right to typeset material by conventional means if an author's disk proves unsatisfactory.

Contributions are invited from all parts of the world. Articles should generally not be more than 8000 words long. The article should be accompanied by an abstract of not more than 100 words. Two copies typed with double spacing should be submitted. A style sheet is available from the editors. The Journal is published in English, but articles may also be submitted in Spanish or Portuguese; if the article is accepted, translation into English will be the responsibility of the author. Tables, diagrams and maps may be included by arrangement with the editors. The Journal only publishes original contributions; translations of articles already published will not be accepted. Each contributor will receive, free of charge, 25 offprints of the article and a copy of the issue of the Journal in which it appears.

The Journal publishes book reviews in each issue. Not all books received can be reviewed and editorial policy gives preference to substantial reviews of books regarded as of major importance for the disciplines covered by the Journal.

All contributions and editorial correspondence should be addressed to Joumal of Latin American Studies, Institute of Latin American Studies, 3 I Tavistock Square, London, WCIH ${ }_{9} \mathrm{HA}$.

\section{COPYRIGHT}

COPYING. This journal is registered with the Copyright Clearance Center, 222 Rosewood Drive, Danvers, MA or923. Organisations in the USA who are also registered with C.C.C. may therefore copy material (beyond the limits permitted by sections 107 and 108 .of US copyright law) subject to payment to C.C.C. of the percopy fee of $\$ 7.50$. This consent does not extend to multiple copying for promotional or commercial purposes. Code $0022-216 \mathrm{x} / 95 \$ 7.50+$.10.

ISI Tear Sheet Service, 350 I Market Street, Philadelphia, Pennsylvania 19104, USA, is authorised to supply single copies of separate articles for private use only.

Organisations authorised by the Copyright Licensing Agency may also copy material subject to the usual conditions.

For all other use, permission should be sought from Cambridge or the American Branch of Cambridge University Press.

\section{CAMBRIDGE UNIVERSITY PRESS}

The Pitt Building, Trumpington Street, Cambridge CB2 IRP

40 West 20th Street, New York, NY 100II-42I I, USA

Io Stamford Road, Oakleigh, Melbourne 3166, Australia 


\section{Journal of}

\section{Latin American Studies}

\section{Volume 27 Part 3 October 1995}

\section{ARTICLES}

The Lawyers and New Granada's Late Colonial State

VICTOR M. URIBE

Physicians, the State and Public Health in Chile, $1881-1891$

CARL J. MURDOCK

Bringing the Countryside Back In: A Case Study of Military Intervention as State Building in the Brazilian Old Republic TODD DIACON

An Historical Critique of the Emergence and Evolution of Ernesto Che Guevara's Foco Theory

MATT D. CHILDS

Explaining Bureaucratic Independence in Brazil: The Experience of the National Economic Development Bank ELIZA J. WILLIS

Central-Bank 'Distress' and Hyperinflation in Argentina,

$1989-90$

PAUL BECKERMAN

\section{COMMENTARY}

Policy-Induced Disincentives to Financial Sector

Development: Selected Examples from Latin America in the $1980 \mathrm{~s}$

IGNACIO MAS

BOOK REVIEWS 